\title{
River network of young glacial areas and its fractal dimension
}

\author{
J. Fac-Beneda \\ Katedra Hydrologii UG, Gdańsk, Poland
}

\begin{abstract}
The environment of the areas of young Pleistocene post-glacial accumulation are characterized by a polygenetic hydrographic network. The hydrographic interpretation method was used to identify the network, and the method of Horton-Strahler and the one by Drwal, to order it. The research covered twelve drainage basins of the Pomeranian Lakeland (north Poland). Maps in 1:50 000, 1:200 000 and 1:500 000 scale were used. The ordering of a network by the Drwal method leads to a decrease in $R_{b}$ and $R_{1}$ values in comparison with analogous values for the Horton-Strahler method (Fig. 3). Generally, value D is higher, often considerably, in hierarchisation by the Drwal method, than by the Horton-Strahler one (Tables 1-3). The reason for this is the fact of taking into consideration 'wild streams' in the Drwal method. The stream length ratio, employed in network analysis, was used to draw empirical straight-lines which were then compared with the theoretical straight-line $\left(R_{1}=2\right)$. The straight-lines drawn on the basis of the values obtained from hierarchisation by the Drwal method have a course definitely closer to the reference straight-line (Fig. 4). This situation does not depend on a map's scale. Among the analysed systems, the best network development and organization characterizes system No 6 .

Keywords: Horton's laws, hierarchisation, fractal dimension, Pleistocene glacial accumulation terrains.
\end{abstract}

\section{Introduction}

The geometrical layout of the river network of the catchment is perceived as a fractal with a dimension characteristic of it [16]. The theoretical, in isolation from the conditions of the environment, fractal dimension of a river network is 2 . For natural river networks, according to La Barbera, Rosso [15] the dimension 
ranges from 1,5 to 2 . Research results indicate that a river network, while reaching the stage of full development, increases its fractal dimension to 2 , hence the reaching of the value of $\mathrm{D}=2$ means a complete filling of the catchment.

The fractal dimension can be calculated by various methods [17,21]. One of them is based on bifurcation ratio and stream length ratio $\left(D=\log R_{b} / \log R_{1}\right)$. In the case of structurally irregular networks, of polygenetic structure, an error in the value of the fractal dimension can occur due to the accuracy of calculation of the number and length of streams [17]. An example of such a network is the network of river systems of Pleistocene glacial accumulation, where the present network uses the previously formed drainage system. This paper analyses the characteristics of river networks, ordering them by different hierarchisation methods.

\section{Study area}

The hydrographical network of the study area, in terms of development and organisation, is characterised by features typical of young Pleistocene postglacial accumulation of south Baltic lakelands. The short time, in the geological scale, which has passed since the withdrawal of the continental glacier results in the fact that at present the network retains many features of a postglacial network [7]. This is manifested in the occurrence of a richness of components of the hydrographic network and the presence of a still poorly organised river network. The young age of the river network is also revealed by a high proportion of lake sections in the upper courses of rivers and the common occurrence of areas without outflow in catchments. For instance, in the catchment of the upper River Radunia, the percentage proportion of lake sections in the river course is as much as $77.8 \%$, and the percentage of areas not included in surface drainage is $42.4 \%$ [6].

The study area covered twelve lakeland basins (Fig.1). Four basins belong to the Vistula River drainage basin (No 1, No 7, No 10, No 12) and one to the Oder River drainage basin (No 3). Seven of the selected basins (No 2, No 4, No 5, No 6, No 8, No 9, No 11) have their drainage base in the Baltic Sea. According to the widely accepted hierarchisation by Gravelius (Atlas..., 2005) there are rivers of order I and called coastal rivers. Rivers No 1, No 10, No 12 are of order II, and the river No 3 and No 7 - order III.

\section{Research methods}

In order to identify the network, the method of hydrographical interpretation, consisting in analysis of the material in terms of the mutual spatial relationship of hydrographical elements, was used. The methods applied to order the network were that by Horton-Strahler and by Drwal; the principle assumptions of the latter are presented below. The base-maps used included: topographic maps of 1:50 000 scale and maps of 1:200 000 from the Atlas of Hydrographical Division of Poland [1] and of 1:500 000 scale from the Hydrological Atlas of Poland [2]. 
In areas of Pleistocene glacial accumulation, the methods of network analysis have been frequently and successfully used [5, 7, 9, 12-14]. The method of network analysis has been used in the case of the ordering of a river network by using both the widely employed Horton-Strahler method as well as the modified method proposed for young glacial areas, taking into consideration the so-called "wild streams" (the Drwal method) [12].

In the Horton-Strahler method, all streams without a supply stream are called the first order. The " $\mathrm{r}+1$ " order stream comes from connecting two streams from the " $r$ " order, the " $r+2$ " order stream comes from connecting two streams from the " $\mathrm{r}+1$ " order, the " $\mathrm{r}+3$ " order stream comes from connecting two streams from the " $\mathrm{r}+2$ " order etc. In this proceeding, the meeting of lower order streams (or their number) is not taken into consideration.

In areas of young Pleistocene post-glacial accumulation, 1, 2 and 3 order streams (called "wild streams") have a rain runoff origin, not connected with glacial activity. It is only in the higher order streams (from 4 upwards) that there appears underground water from deep circulation. For an analysis of the networks of these terrains, it is necessary to consider these "wild streams". The Drwal method, proposed and checked earlier in areas of young Pleistocene glacial accumulation, does take the "wild streams" into consideration [5, 7-9].

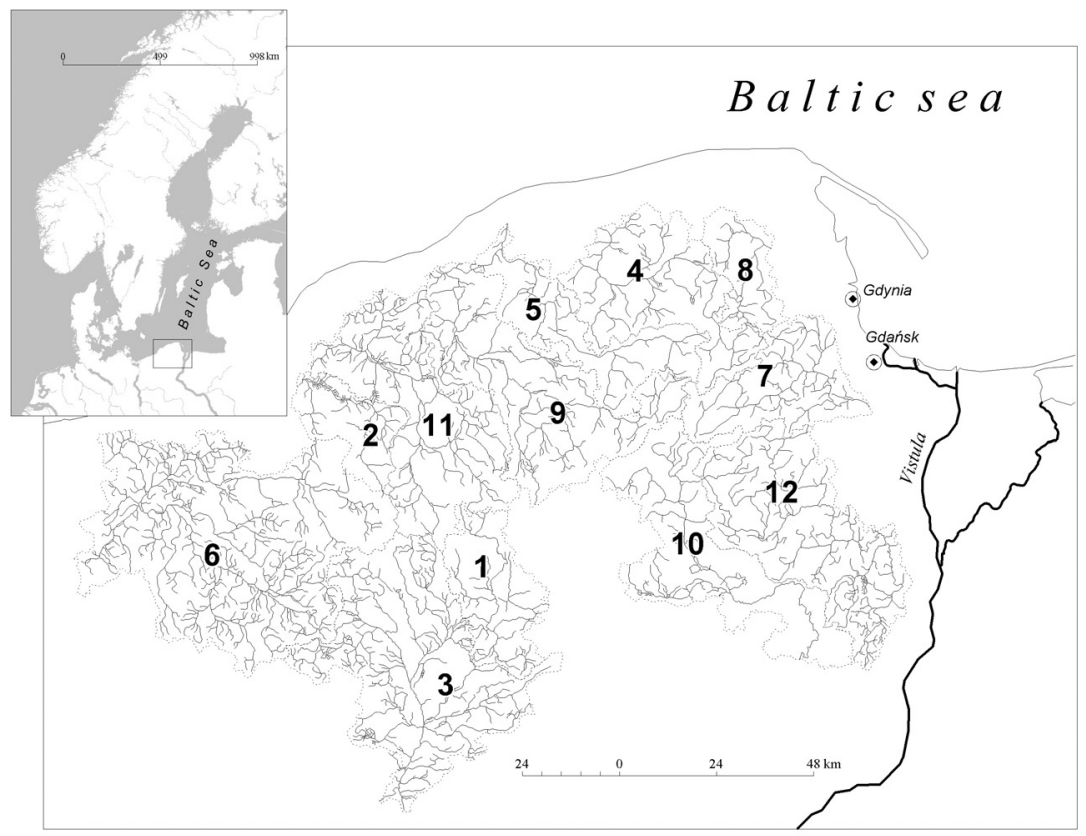

Figure 1: $\quad$ The study area (researched basins were marked as 1-12). 

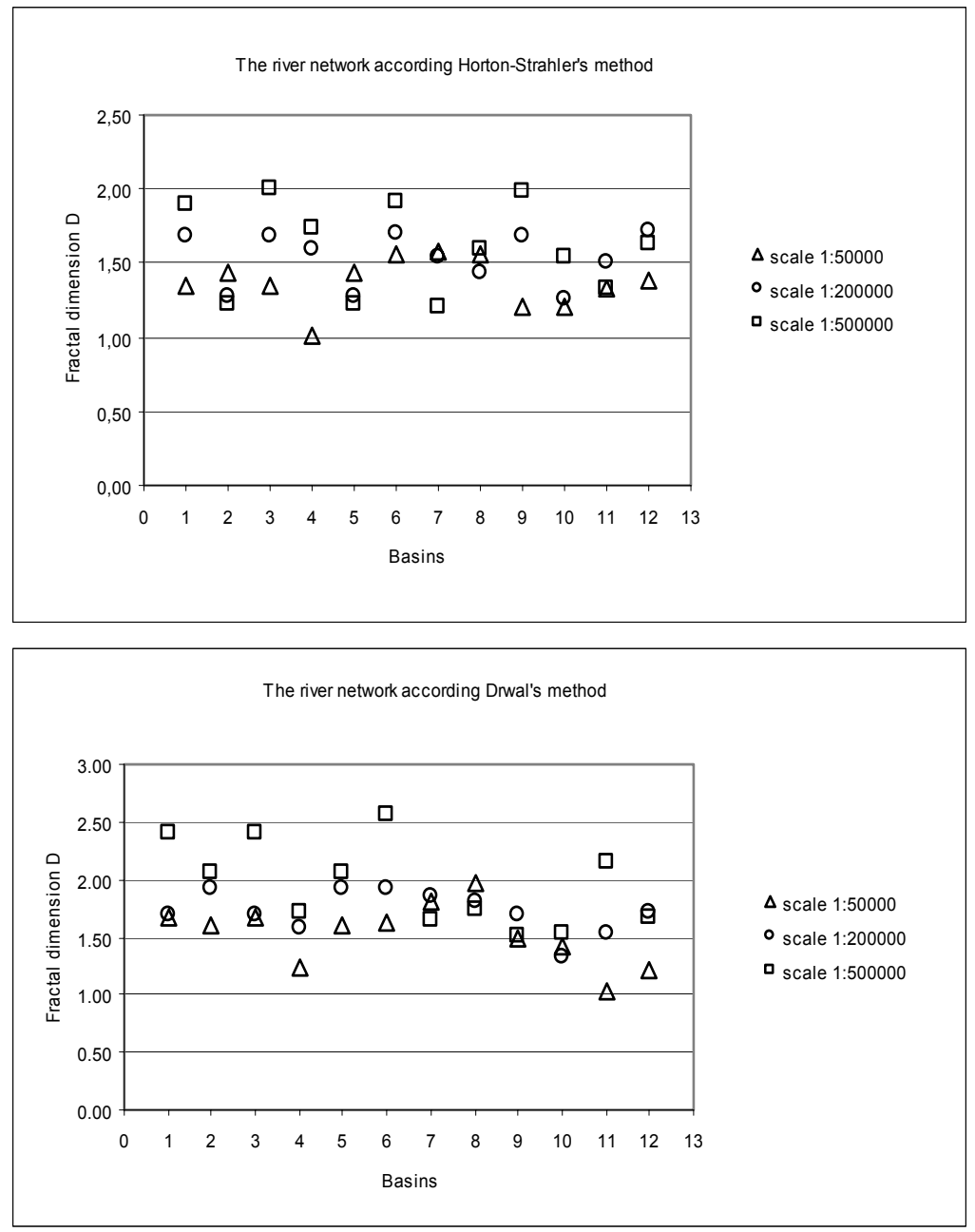

Figure 2: The fractal dimension according both method hierarchization and in different scale.

There are two rules of proceeding in the Drwal method. The first principle (primary) is the same as the proceeding in the Horton-Strahler method. The second principle (supplementary) tells us that the " $r+1$ " order stream can also appear when the " $r$ " order stream accepts such a number of "wild streams" which will balance the lack of the second " $r$ " order stream. And so, for example, an " $r+3$ " order stream arises when there meet two " $r+2$ " order streams, but it also arises when one " $\mathrm{r}+2$ " order stream accepts two " $\mathrm{r}+1$ " order streams, or when it accepts one " $r+1$ " order stream and four " $r$ " order streams, or eight " $r$ " order streams [12]. 


\section{Analysis of young glacial natural network}

The fractal dimension is a value which depends on the assumed observation scale, and the smaller the scale the higher the fractal dimension $[3,4,15,16,18]$. Not in all cases is this rule confirmed and this is so irrespective of the employed hierarchisation method (Fig. 2). In Drwal's hierarchisation -7 cases in accordance with the rule; in Horton-Strahler's - 5 cases. This probably results from the fact that the hydrographical content on a topographic map, during transition from a larger to smaller scale, is more often qualitatively than quantitatively generalized [20], and due to that value D becomes distorted. Generally, value D is higher, often considerably, when using Drwal's hierarchisation method than that by Horton-Strahler (in 9-11 cases depending on scale) (Tables 1-3). The reason for this is the fact of taking into consideration "wild streams" in the Drwal method.

Table 1: $\quad$ Morphometric parameters of the researched basins in scale 1:50 000 (H-S: Horton-Strahler method, Dr: Drwal method).

\begin{tabular}{|c|c|c|c|c|c|c|c|c|c|c|c|c|}
\hline \multirow[t]{2}{*}{$\mathrm{No}$} & \multirow[t]{2}{*}{ Basin } & \multirow[t]{2}{*}{$\mathrm{A}\left[\mathrm{km}^{2}\right]$} & \multirow[t]{2}{*}{$\mathrm{L}[\mathrm{km}]$} & \multirow{2}{*}{$\begin{array}{c}\mathrm{G} \\
{[\mathrm{km} / \mathrm{km} 2]}\end{array}$} & \multicolumn{2}{|c|}{ Order } & \multicolumn{2}{|c|}{$\mathrm{R}_{\mathrm{b}}$} & \multicolumn{2}{|c|}{$\mathrm{R}_{1}$} & \multicolumn{2}{|c|}{ D } \\
\hline & & & & & H- & Dr & $\mathrm{H}-\mathrm{S}$ & Dr & $\mathrm{H}-\mathrm{S}$ & Dr & $\mathrm{H}-\mathrm{S}$ & $\mathrm{Dr}$ \\
\hline 1. & Brda & 668.43 & 593.47 & 0.89 & 5 & 8 & 5.24 & 2.99 & 3.92 & 2.09 & 1.35 & 1.67 \\
\hline 2. & Grabowa & 456.68 & 352.59 & 0.77 & 5 & 7 & 4.45 & 2.97 & 2.84 & 1.97 & 1.43 & 1.60 \\
\hline 3. & Gwda & 2042.40 & 1951.18 & 0.96 & 6 & 9 & 4.67 & 2.82 & 3.32 & 1.86 & 1.35 & 1.67 \\
\hline 4. & Łeba & 1099.03 & 1134.71 & 1.03 & 6 & 8 & 4.30 & 3.09 & 4.22 & 2.51 & 1.01 & 1.23 \\
\hline 5. & Lupawa & 807.27 & 679.34 & 0.84 & 5 & 7 & 5.31 & 3.73 & 5.36 & 2.49 & 1.43 & 1.60 \\
\hline 6. & Parsęta & 2884.97 & 3696.77 & 1.28 & 7 & 9 & 4.05 & 2.93 & 2.45 & 1.94 & 1.56 & 1.62 \\
\hline 7. & Radunia & 790.54 & 755.34 & 0.96 & 6 & 8 & 3.95 & 2.95 & 2.38 & 1.82 & 1.59 & 1.81 \\
\hline 8. & Reda & 409.99 & 494.34 & 1.21 & 6 & 8 & 3.96 & 2.83 & 2.42 & 1.69 & 1.55 & 1,97 \\
\hline 9. & Słupia & 1597.79 & 1854.49 & 1.16 & 6 & 9 & 5.01 & 2.99 & 3.19 & 1.94 & 1.21 & 1,48 \\
\hline 10. & Wda & 1374.45 & 1231.62 & 0.90 & 6 & 8 & 4.79 & 3.07 & 3.67 & 2.21 & 1.21 & 1,42 \\
\hline 11. & Wieprza & 1541.99 & 1850.31 & 1.20 & 6 & 8 & 4.96 & 3.09 & 3.32 & 2.99 & 1.33 & 1,03 \\
\hline 12. & Wierzyca & 1543.36 & 1541.49 & 1.00 & 6 & 8 & 4.35 & 2.96 & 2.89 & 2.43 & 1.39 & 1,22 \\
\hline
\end{tabular}

Values $R_{b}$ and $R_{1}$ on the three analysed scales are constant and reveal the following relationship $R_{1}=\alpha R_{b}$ with $\alpha$ approximately constant: 0.66 for both hierarchisation. The ordering of the network by the Drwal method leads to a decrease in values $R_{b}$ and $R_{l}$ in comparison with analogous values for the method of Horton-Strahler (Fig. 3). These values for the analysed catchments are moreover closer to each other using the Drwal method, which can confirm their location in similar environmental conditions.

The stream length ratio, employed in network analysis [9, 11, 15, 21], was used to draw empirical straight-lines which were then compared with the 
Table 2: $\quad$ Morphometric parameters of the researched basins in scale 1:200 000 (H-S: Horton-Strahler method, Dr: Drwal method).

\begin{tabular}{|c|c|c|c|c|c|c|c|c|c|c|c|c|}
\hline \multirow[t]{2}{*}{ No } & \multirow[t]{2}{*}{ Basin } & \multirow[t]{2}{*}{$\mathrm{A}\left[\mathrm{km}^{2}\right]$} & \multirow[t]{2}{*}{$\mathrm{L}[\mathrm{km}]$} & \multirow{2}{*}{$\begin{array}{c}\mathrm{G} \\
{\left[\mathrm{km} / \mathrm{km}^{2}\right]}\end{array}$} & \multicolumn{2}{|c|}{ Order } & \multicolumn{2}{|c|}{$\mathrm{R}_{\mathrm{b}}$} & \multicolumn{2}{|c|}{$\mathrm{R}_{\mathrm{l}}$} & \multicolumn{2}{|c|}{ D } \\
\hline & & & & & $\mathrm{H}-\mathrm{S}$ & Dr & $\mathrm{H}-\mathrm{S}$ & Dr & $\mathrm{H}-\mathrm{S}$ & Dr & $\mathrm{H}-\mathrm{S}$ & $\mathrm{Dr}$ \\
\hline 1. & Brda & 668.43 & 363.08 & 0.54 & 5 & 6 & 3.72 & 2.86 & 2.17 & 1.85 & 1.68 & 1.70 \\
\hline 2. & Grabowa & 456.68 & 385.76 & 0.84 & 4 & 7 & 6.06 & 3.06 & 4.09 & 1.79 & 1.28 & 1.92 \\
\hline 3. & Gwda & 2042.40 & 1540.68 & 0.75 & 6 & 8 & 4.00 & 2.78 & 2.29 & 1.83 & 1.68 & 1.70 \\
\hline 4. & Łeba & 1099.03 & 659.27 & 0.60 & 5 & 7 & 4.41 & 2.97 & 2.53 & 2.00 & 1.60 & 1.57 \\
\hline 5. & Lupawa & 807.27 & 537.99 & 0.67 & 5 & 7 & 4.22 & 2.94 & 3.64 & 2.17 & 1.28 & 1.92 \\
\hline 6. & Parsęta & 2884.97 & 2842.28 & 0.99 & 7 & 9 & 4.00 & 2.86 & 2.29 & 1.73 & 1.70 & 1.93 \\
\hline 7. & Radunia & 790.54 & 559.94 & 0.71 & 6 & 7 & 3.18 & 2.73 & 2.12 & 1.72 & 1.54 & 1.86 \\
\hline 8. & Reda & 409.99 & 271.90 & 0.66 & 5 & 6 & 3.88 & 2.92 & 2.58 & 1.81 & 1.43 & 1.81 \\
\hline 9. & Słupia & 1597.79 & 913.84 & 0.57 & 6 & 8 & 3.67 & 2.74 & 2.39 & 1.71 & 1.69 & 1.70 \\
\hline 10. & Wda & 1374.45 & 1260.12 & 0.92 & 6 & 8 & 4.90 & 3.06 & 3.55 & 2.12 & 1.26 & 1.32 \\
\hline 11. & Wieprza & 1541.99 & 1277.69 & 0.83 & 6 & 8 & 4.31 & 3.02 & 2.64 & 2.06 & 1.50 & 1.53 \\
\hline 12. & Wierzyca & 1543.36 & 1248.90 & 0.81 & 6 & 8 & 4.16 & 2.99 & 2.30 & 1.90 & 1.71 & 1.71 \\
\hline
\end{tabular}

Table 3: Morphometric parameters of the researched basins in scale 1:500 000 (H-S: Horton-Strahler method, Dr: Drwal method).

\begin{tabular}{|c|c|c|c|c|c|c|c|c|c|c|c|c|}
\hline \multirow[t]{2}{*}{$\mathrm{Nc}$} & \multirow[t]{2}{*}{ Basin } & \multirow[t]{2}{*}{$\mathrm{A}\left[\mathrm{km}^{2}\right]$} & \multirow[t]{2}{*}{$\mathrm{L}[\mathrm{km}]$} & \multirow{2}{*}{$\begin{array}{c}\mathrm{G} \\
{\left[\mathrm{km} / \mathrm{km}^{2}\right]}\end{array}$} & \multicolumn{2}{|c|}{ Order } & \multicolumn{2}{|c|}{$\mathrm{R}_{\mathrm{b}}$} & \multicolumn{2}{|c|}{$\mathrm{R}_{1}$} & \multicolumn{2}{|c|}{$\mathrm{D}$} \\
\hline & & & & & $\mathrm{H}-\mathrm{S}$ & $\mathrm{Dr}$ & $\mathrm{H}-\mathrm{S}$ & $\mathrm{Dr}$ & $\mathrm{H}-\mathrm{S}$ & Dr & H-S & Dr \\
\hline 1. & Brda & 668.43 & 259.99 & 0.39 & 4 & 5 & 3.53 & 2.65 & 1.89 & 1.90 & 1.89 & 2.41 \\
\hline 2. & Grabowa & 456.68 & 207.15 & 0.45 & 4 & 5 & 4.55 & 3.58 & 3.44 & 1.86 & 1.23 & 2.06 \\
\hline 3. & Gwda & 2042.40 & 1057.46 & 0.52 & 5 & 7 & 3.88 & 2.66 & 1.97 & 1.50 & 2.00 & 2.41 \\
\hline 4. & Łeba & 1099.03 & 404.68 & 0.37 & 4 & 5 & 3.98 & 2.86 & 2.22 & 1.84 & 1.73 & 1.73 \\
\hline 5. & Lupawa & 807.27 & 261.34 & 0.32 & 4 & 5 & 3.71 & 3.03 & 2.81 & 2.13 & 1.23 & 2.06 \\
\hline 6. & Parsęta & 2884.97 & 1592.61 & 0.55 & 5 & 7 & 4.53 & 2.85 & 2.21 & 1.50 & 1.91 & 2.57 \\
\hline 7. & Radunia & 790.54 & 318.28 & 0.40 & 4 & 5 & 3.78 & 2.78 & 3.01 & 1.86 & 1.21 & 1.65 \\
\hline 8. & Reda & 409.99 & 142.52 & 0.35 & 3 & 4 & 5.25 & 3.17 & .82 & 1.94 & 1.60 & 1.74 \\
\hline 9. & Słupia & 1597.79 & 592.72 & 0.37 & 5 & 6 & 3.40 & 3.05 & 1.76 & 1.62 & 1.98 & 1.52 \\
\hline 10. & $\mathrm{Wda}$ & 1374.45 & 719.00 & 0.52 & 4 & 5 & 5.47 & 3.35 & 3.02 & 2.21 & 1.54 & 1.52 \\
\hline 11. & Wieprza & 1541.99 & 683.06 & 0.44 & 4 & 6 & 5.96 & 3.40 & 3.82 & 1.76 & 1.33 & 2.16 \\
\hline 12. & Wierzyca & 1543.36 & 728.74 & 0.47 & 5 & 6 & 3.54 & 2.81 & 2.17 & 1.86 & 1.63 & 1.67 \\
\hline
\end{tabular}

theoretical straight-line $\left(\mathrm{R}_{\mathrm{l}}=2\right)$. The lines drawn on the basis of the values obtained from hierarchisation by the Drwal method have a course much closer to the reference line in 31 of 36 cases. This situation does not depend on a map's scale. Only for the network no 6 interpreted on 1:200 000 and 1:500 000 scales, 


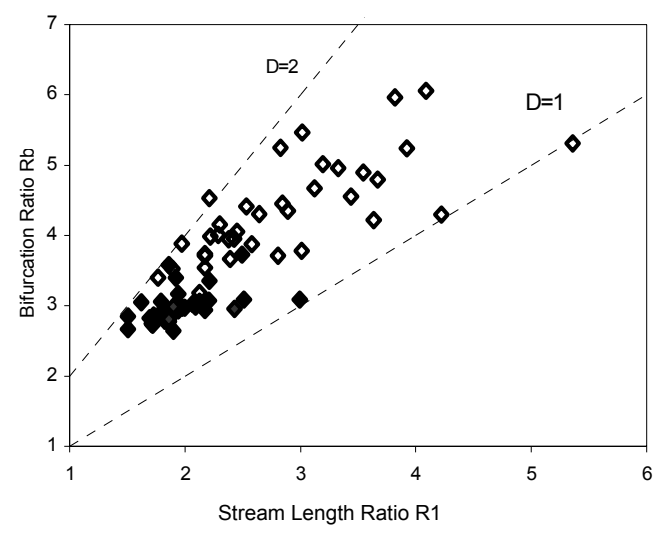

Figure 3: $\quad R_{1}$ versus $R_{b}$ for different values of fractal dimension $D$. Black squares represent the observed values in Drwal's method, empty squares represent the observed values in Horton-Strahler's method.

for the network no 7 interpreted on 1:200 000 scale and for the network no 3 and no 9 interpreted on 1:500 000 scale, has the so-called Horton line a course closer to the reference line. Figure 4 presents these lines in three scales for the selected basin (no 5).

\section{Conclusions}

It was assumed that the best-developed network is such whose fractal dimension on 1:50 000 scale ranges from 1.5 to 2 [15] and whose fractal dimension in both methods has a similar value. Of the analysed systems the best network development and organisation is observed in basin no 6 (Tables 1-3). This is also the basin of the largest mean density of the river network (1.28 on 1:50 000 scale, 0.99 on 1:200 000, 0.55 on 1:500 000). It seems that for the purposes of research concerning network analysis, it is inadvisable to use maps on 1:500 000 scale as values of the fractal dimension on this scale in many cases fall outside the range assumed for the fractal dimension of river networks.

Bajkiewicz-Grabowska and Olszewski [3] indicate that the vectorial fractal dimension of a network ordered by the Horton-Strahler method describes an idealized network, and the more the actual network differs from this model, the less reliable the results are. It seems that the actual network (with "wild streams") is well described if it is ordered using the Drwal method. The values calculated for networks ordered by this method are closer to the values for the idealized network.

The values of ratios, thus also of the fractal dimension, depend not only on the adopted hierarchisation method but also on the conditions of the geographic environment of the basin $[9,10,19]$. Thus, the acceptance or rejection of a particular hierarchisation method should depend on them. 

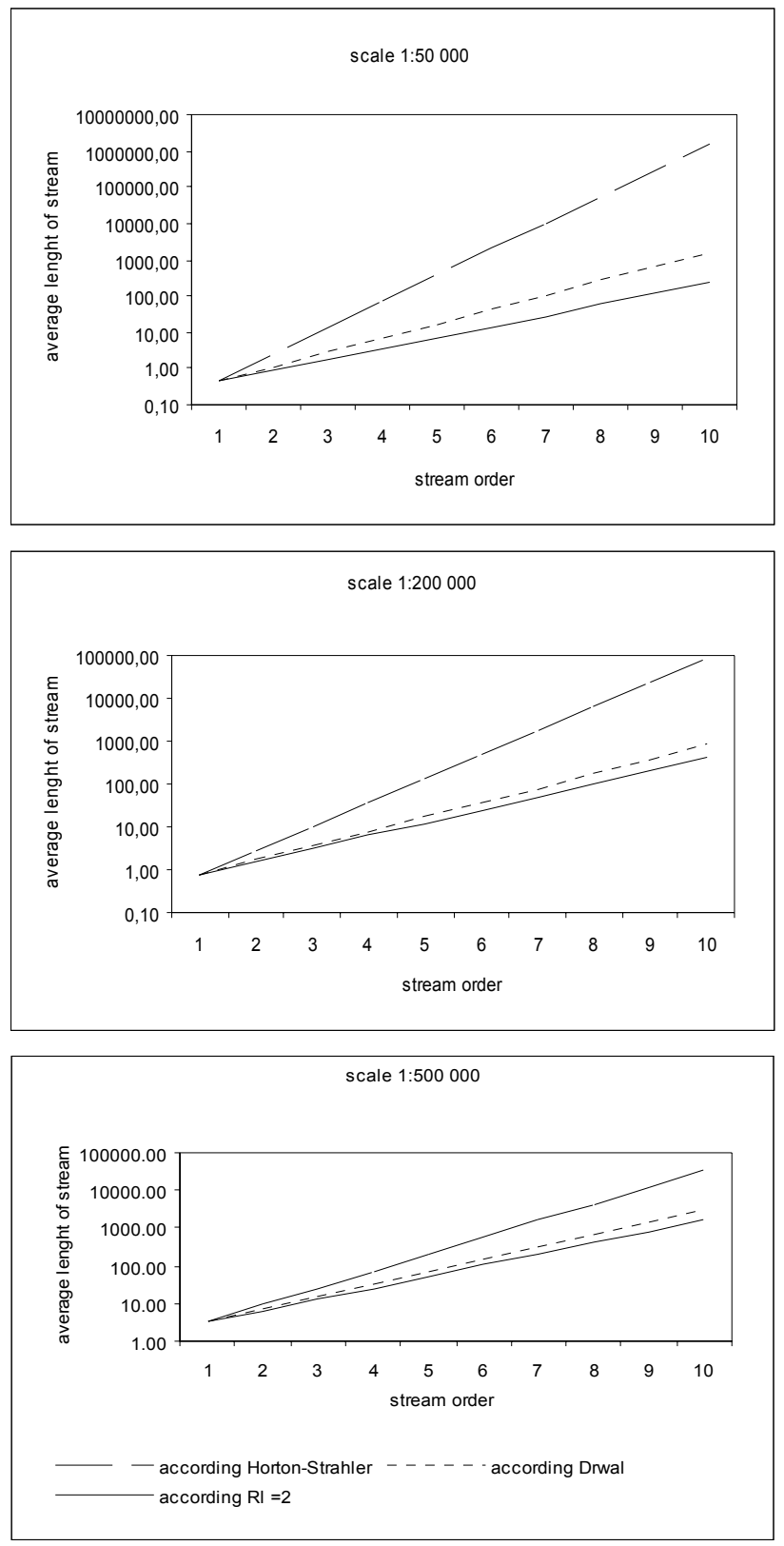

Figure 4: Theoretical and empirical stream length ratio $\left(\mathrm{R}_{1}\right)$ for basin no 5 in scale 1:50 000 . 
In the light of the above, it seems that the appropriate method for river systems of young glacial areas is that by Drwal. The network of such areas ordered by the Horton-Strahler method, despite meeting the conditions of the Horton network, does not offer an actual picture of the structure of young glacial systems. Reassuming, the proposed method of network ordering (Drwal method) yields better results than the classic one by Horton-Strahler and can be applied to a river network in the conditions of young Pleistocene glacial accumulation.

\section{Acknowledgements}

The work was supported by the Ministry of Science and Higher Education (grant No 2764/B/P01/2008/35

\section{References}

[1] Czarnecka, H., (eds). Atlas Podziatu Hydrograficznego Polski, ZHiMKR, IMGW, Warszawa, 2005.

[2] Czarnecka, H., (eds). Atlas Hydrologiczny Polski, t. I, IMGW, Wyd. Geol., Warszawa, 1987.

[3] Bajkiewicz-Grabowska, E. \& Olszewski, R., Czy prawa Hortona poprawnie opisują fraktalną strukturę sieci rzecznych? Przegl. Geofiz., XLVI, z. 3, pp.223-239, 2001.

[4] Bajkiewicz-Grabowska, E., Obieg materii w systemach rzeczno-jeziornych, Uniwersytet Warszawski, Wydział Geografii i Studiów Regionalnych, Warszawa, 2002.

[5] Bogdanowicz, R., Struktura hydrograficzna decentrycznego systemu odwadniania Wzniesienia Elblaskieg. Sprawozdania GTN, GTN, Gdańsk, 1993.

[6] Borowiak, M., Struktura hydrograficzna i lokalne warunki obiegu wody. Jeziora górnej Raduni i jej zlewnia w badaniach z udziałem Stacji Limnologicznej w Borucinie, eds. W. Lange, Badania Limnologiczne no 3, Katedra Limnologii UG, Gdańsk, pp. 127-141, 2005.

[7] Drwal, J., Wykształcenie i organizacja sieci hydrograficznej jako podstawa oceny struktury odpływu na terenach młodoglacjalnych. Zesz. Nauk. UG, Rozprawy i monografie, no 33, Gdańsk, 1982.

[8] Drwal, J., Personal communication, 1994, Geograficzna interpretacja systemów hydrograficznych (w terenach młodej plejstoceńskiej akumulacji polodowcowej), Gdańsk, PL.

[9] Drwal, J. \& Bogdanowicz, R., Stosowalność klasyfikacji hydrograficznych o tak zwanym odwróconym porządku numeracji w analizie sieci rzecznej wybranej zlewni przymorza. Zesz. Nauk. Wydz. BGiO UG, Geografia, no 15 , pp. 109-119, 1986.

[10] Dynowska, I. \& Dobija, A., Znaczenie parametrów fizjograficznych zlewni dla ustalenia wielkości odpływu rzecznego. Folia Geographica, Series Geographica-Physica, vol. IX., pp. 77-127, 1975.

[11] Eagleson, P.S., Hydrologia dynamiczna, PWN, Warszawa, 1978. 
[12] Fac-Beneda, J., Wymiar fraktalny sieci rzecznej uporządkowanej metodą Hortona-Strahlera i metodą Drwala. Ewolucja Pojezierzy $i$ Pobrzeży Południowobattyckich u schyłku ostatniego glacjatu $i w$ holocenie, ed. R. Gołębiewski, Gdańsk, pp. 27-36, 2003.

[13] Fac-Beneda, J., Wielkość odpływu ze zlewni niekontrolowanych hydrometrycznie określona metodą redukcji na przykładzie dorzecza Łupawy i Słupi. Zintegrowany monitoring środowiska przyrodniczego, Funkcjonowanie geoekosystemów Polski $w$ warunkach zmian klimatu $i$ różnokierunkowej antropopresji, eds. A. Kostrzewski \& R. Kolander, Biblioteka Monitoringu Środowiska, Poznań, pp. 283-291, 2005.

[14] Fac-Beneda, J., Formowanie się i organizacja odpływu w systemie Słupi, Łupawy i Łeby. Obieg wody w środowisku naturalnym i przeksztatconym, ed. Z. Michalczyk, Badania Hydrograficzne w poznawaniu środowiska, t.VIII, pp.203-210, UMCS, 2007.

[15] La Barbera, P. \& Rosso, R., On the Fractal Dimension of Stream Networks. Water Resour. Res., vol. 56, no. 4, pp. 735-741, 1989.

[16] Mandelbrot, B. B., The Fractal Geometry of Nature. W. H. Freeman, New York, 1983.

[17] Magnuszewski, A., Wymiar fraktalny współczesnych sieci rzecznych. Przegl. Geofiz., XXXVIII, z.2, s. 121-130, 1993.

[18] Nikora, W. I., Fractal structures of river plan forms. Water Resour. Res., vol. 27, no. 6, pp. 1327-1333, 1991.

[19] Rzhanitsyn, N.A., Mofołogiczeskije i gidrołogiczeskije zakonomiernosti strojej recznoj seti, Gidromietieorołogiczieskoe Izdatie, Leningrad, 1960.

[20] Szaflarski, J., Zarys kartografii, PWN, Warszawa, 1965.

[21] Veltri, M. \& Veltri, P. \& Maiolo, M., On the fractal description of natural channel networks. Journal of Hydrology, 187, pp.137-144, 1996. 